\title{
REFLECTIONS ON APPLYING CRITICAL DISCOURSE ANALYSIS METHODOLOGIES IN ANALYSING SOUTH AFRICAN HISTORY TEXTBOOKS
}

\author{
DOI: http://dx.doi.org/10.17159/2223-0386/2015/n14a3 \\ Marshall Tamuka Maposa \\ School of Education \\ University of KwaZulu-Natal \\ maposam2@ukzn.ac.za
}

\section{Abstract}

This article is a reflection on the choice to apply Critical Discourse Analysis (CDA) in a large scale study in which South African history textbooks were analysed for their construction of African consciousness. The article begins with an evaluation of history textbooks analysis as a field of study. It then explains my rationale for adopting CDA in a field where most studies are qualitative content analyses. This is followed by the explanation of my practical adaptation and application of Norman Fairclough's version of CDA mixed with functional linguistics and visual semiotics. Only a few examples of the findings in the larger scale study are given to elaborate on this application. The article ends with a reflective evaluation of my application of CDA. I conclude that, though fraught with challenges, the application of CDA offers a worthwhile alternative methodology in the analysis of history textbooks.

Keywords: Critical Discourse Analysis (CDA); History textbooks; Methodologies; Africa; Africanness; South Africa.

\section{Introduction, contextualisation and research problem}

History textbook research can be considered, at the very least, to be a century old. One landmark development in history textbook research was the Casares Resolution of 1925 through which the League of Nations commended early forms of textbook analysis and recommended even more research in the field. Since then, huge strides have been made in the field of textbook research, with notable developments such as the establishment and growth of the Georg Eckert Institute for international textbook research located in Braunschweig, Germany. In spite of the evident expansion, textbook research in general has not taken a significant position in mainstream education research (Johnsen, 2001). 
In relation to the shortcomings of textbook analysis, Weinbrenner (1992) lamented the absence of any specific theory guiding textbook analysis methodologies. A generation later, this claim is still arguably valid; resulting in a continued undervaluing of textbook analysis studies. Indeed, textbook analysis still remains not clearly defined - sometimes referred to as document study/analysis or secondary analysis (Cohen, Manion \& Morrsion, 2009; Strydom \& Delport, 2010). This undervaluing of textbook analysis is rather regrettable, particularly if one considers the critical role that textbooks still play in education systems throughout the world. Despite technological advancements, the textbooks sector remains a multi-billion industry and textbooks remain the most utilised form of educational media (Foster \& Crawford, 2006; Lavere, 2008; Selander, 2008; Swanson, 2014).

Many methods have been applied in the analysis of history textbooks, including content analysis, hermeneutic analysis and discourse analysis. According to Nicholls (2003), qualitative forms of content analysis have been the most dominant methods to be used by history textbook analysts. This means that there are still opportunities for the employment of other methods. It has been quite evident that methodological choices, amongst other choices, can have a huge bearing on the findings of textbook analyses. In addition, the nature of the study focus may require researchers to use methods other than content analysis. For example, discourse analysis methods transcend content analyses in that they may be useful in studies which aim to reveal underlying and contextualised meanings of text (Firer, 1998; Lebrun et al., 2002; Nicholls, 2003; Mouton, 2011).

There are many forms of discourse analyses, but in this study I will focus on Critical Discourse Analysis (CDA). One outstanding application of CDA in history textbook analysis is by Barnard (2003) who published in his book Language, ideology, and Japanese history textbooks in which the linguistic tenets of CDA were used to reveal the influence of the context in how textbook producers use language, ultimately also playing their part in the socialisation process. Nevertheless, there is very little evidence of CDA methodologies being applied in the analysis of history textbooks (Nicholls, 2003; Oteíza \& Pinto, 2008; Morgan, 2010; Pingel, 2010: Morgan \& Henning, 2013).

It is on the basis of the foregoing background that I present in this paper some reflections on the application of CDA as a methodology with which to analyse history textbooks. The critical question that this paper aims to answer is: How can CDA methodologies be applied in the analysis of history 
textbooks? The reflections in this paper stem from a larger-scale study in which I analysed the construction of African consciousness in South African History textbooks (Maposa, 2014). In the larger study, I analysed four contemporary Grade 12 South African history textbooks. Within the selected textbooks, I only analysed the chapters/units that deal with postcolonial Africa. I applied a CDA methodology to describe, interpret and explain how the text represents Africa and Africanness, thus constructing a particular African consciousness to which the textbook users would be exposed. The study was theoretically framed within discursive postcolonialism and premised under a social constructionist paradigm.

I will firstly explain the issues around my choice of CDA after which I will explain how I used it giving a few examples from the findings of the larger scale study. This paper will not dwell on presenting the detailed findings of the construction of African consciousness in South African history textbooks as they can be found in other papers.

\section{Rationale for CDA methodologies}

The nature of the field of history education dictates that qualitative methodologies are dominant. To explain the appropriateness of qualitative methodologies, Firer (1998:196) argues that the history textbook analyst engages with "the art of persuasion and his business is to analyse the apparent, the implied, the hidden, and the missing in curricula and textbooks". It is also for this reason that she recommends that textbook analysts should sometimes transcend content analyses and apply discourse analysis methods such as CDA. Henning, van Rensburg and Smit (2005:117) warn that "the analysis of data for discourse purposes is both similar to and different from content analysis." In addition to being influenced by my theoretical and paradigmatic orientations, my decision to use CDA was bolstered by considerations of how CDA methodologies regard text (language) and context.

The growth of discourse theory (from which CDA stems), was centred on the linguistic turn, which emphasised the nature of language and how the understanding of language enhances the understanding of social phenomena. Johnsen (2001:34) states a case for CDA in textbook analysis thus: "Language mastery has become essential in view of our daily contact with print and electronic texts". Language is closely related to text in that language can be represented through text, and text can in turn generate language (through 
meaning). In this case text includes both verbal and visual signs (LaSpina, 1998; Väisänen, 2008). Therefore it is language that enables text to maintain coherence and gain and (conversely) construct meaning (Peräkylä, 2005). Focusing on language in the history textbooks that I analysed did not necessarily imply abandoning engagement with the historical content. Rather, it enabled me to engage with the manner in which the content was represented through language, in the process constructing a particular African consciousness for the textbook audience. The basis of such an approach is that language choices in the writing of text are conscious decisions that are taken for a particular end.

CDA also emphasises considering the context of the text whenever analysis takes place. In relation to textbook research methodologies, Crawford (2000) identifies three contexts: influence, text production, and practice. The context of influence is explained by Crawford (2000:1) to be the setting "where the ideological and political basis of policy is debated and decided by government and powerful interest groups". In this context, understanding hegemony is important because it is within this setting that the powerful groups of society exercise their respective influence to determine what the learners ought to learn in schools. All policy is based on particular ideological fundamentals, but textbook production is not only about political power, as other forms of power (such as economic power) are significant. It is within such contexts that the educational discourse of a country is established (Naseem, 2008). It is not a coincidence, for example that a fundamentally combating government in Palestine would produce a military educational discourse as Naseem (2008) argues. Therefore in choosing CDA, I had to be sure that I have a competent grasp of the discourses on Africa and Africanness that emerge from the macrolevel of the context- in this case South Africa.

I did not delimit the context of influence to the geopolitical space of countries. I took cognisance of the fact that the country under focus may belong to international bodies to which heads of states submit their policies and practices. To explain, South Africa may be a sovereign state, but its policies and discourses may be influenced by bodies such as the Southern African Development Community (SADC) and the African Union (AU) to which it belongs. It is of particular importance to note that the political leaders might have different discourses and discourse practices in their respective countries, but when they are at regional and continental forums, they invariably speak similar discourses informed by the postcolonial African condition, even if it 
is mere political posturing. I therefore considered the discourses from such contexts of influence when analysing the selected textbooks.

The application of CDA in history textbook analysis assumes that the hegemonic groups in the context of influence and text production are also the same stakeholders who endorse textbooks for use in schools. In some contexts the state holds virtually sole hegemony, but in other contexts even apolitical groups such as civil organisations are also involved to ensure that the textbooks are representative of diverse society and also correspond with the expectations of curriculum policy. This is the context of text production "where texts deemed to represent policy are constructed" (Crawford, 2000:19). While my study was not specifically focused on hegemonic practices, I still took into consideration how power struggles and how the interests of the dominant group are exposed through CDA. In South Africa, the Department of Basic Education reserves the right to approve textbooks that fit their criteria. Still, this does not mean that the production of the text is the sole responsibility of the state. As Lebrun et al., (2002) note, the parties involved in the context of text production include authors, editors, technical and scientific advisors, publishers, the printers, the illustrators and layout artists, evaluators and the market. Critical engagement with the socio-educational context within which textbooks are produced constitutes one of the major differences between content analysis and CDA (Lebrun et al., 2002).

I was mindful of the fact that CDA methodology is not originally fashioned for history textbook research. Nonetheless, I was aware that it has been applied in many fields, education included (Rogers, 2003). Applying CDA to the analysis of textbooks meant that I was practicing an interdisciplinary methodology. This is not strange in textbook analysis if one works under the premise that interdisciplinarity strengthens studies. Indeed, according to Johnsen (2001:24) "linguistics, pedagogics, philosophy, history, sociology and psychology are just a few of the traditional disciplines that are applied singly or in combination in textbook analyses".

I therefore made the decision to conduct a CDA study with the intention of applying the insights explained above. The textual analysis that I conducted was not meant to reveal just apparent meaning, but hidden connotations. This is because "it is never possible to read meaning directly off the verbal and visual textual signs" (Janks, 1997:332). Based on this, the application of CDA was meant to reveal the textbook producers' construction of African consciousness even in cases where they tried to hide it through using seemingly neutral language. 


\section{Application of CDA}

Just as there are different forms of discourse analysis, there are also several variations of CDA, explanations of which would surfeit the limited bounds of this paper. I focused on Norman Fairclough's CDA whose main characteristic is the merger of some key concerns of linguistic and critical social research (Peräkylä, 2005). The critical aspect is represented by an analysis of how power influences the reproduction and legitimation of knowledge. In the case of my study, I worked under the premise that power influences the way the textbooks represent Africa and Africanness, such that they legitimate the African consciousness that is constructed for the textbook user. What was most relevant for my application of Fairclough's CDA model is its guidance on the three dimensions of analysis as shown in Image 1 (Fairclough, 1995:98; Janks, 1997:330). These three dimensions of analysis were applied to both the verbal and visual data. Although the model in Image 1 was conceptualised by Fairclough (1995), I relied mainly on Janks (1997) on the basis of how he applied the model in analysing discourses in South African media.

Image 1: Methodological framework - Fairclough's CDA dimensions of analysis

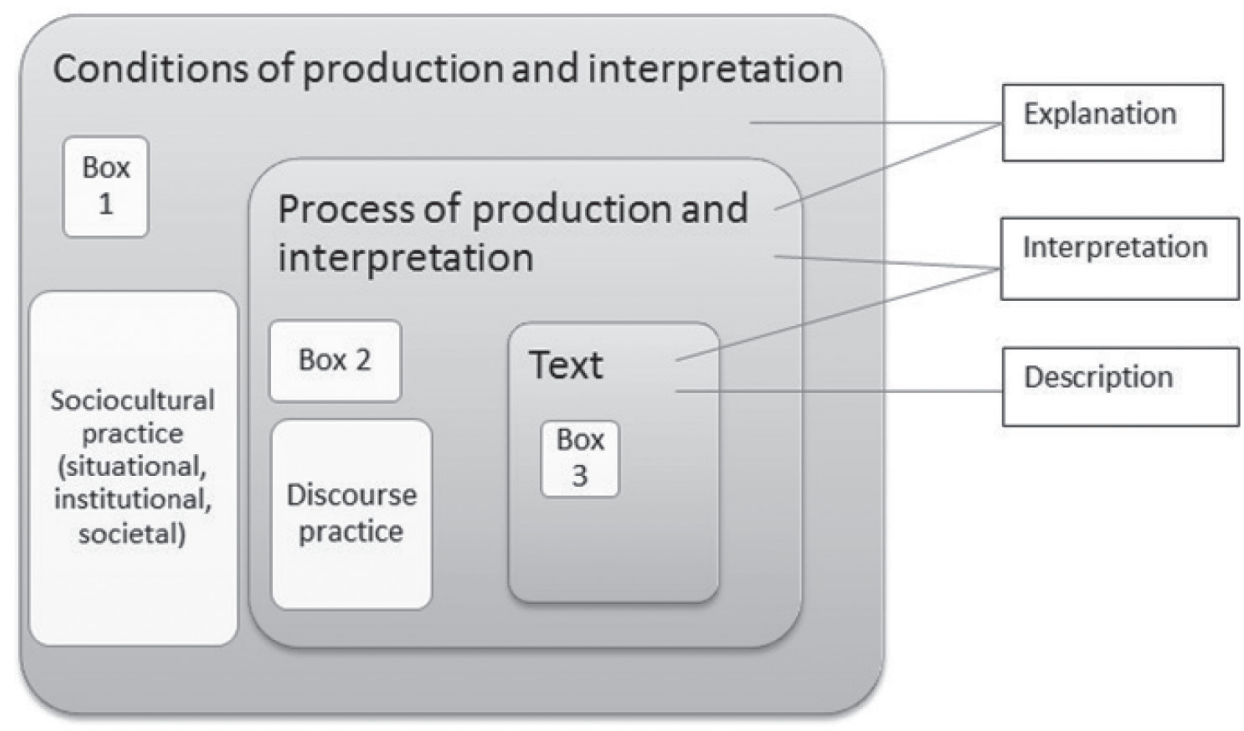

Source: Fairclough, 1995:98; Janks, 1997:330. 


\section{Description: Verbal text}

As an entry point, I worked "from text to discourse" meaning that I started within the box of description (Janks, 1997:331). I analysed the verbal text as recommended by Janks (1997) such that other forms of text (visual text) would fill in the gaps and complement the verbal text when I reached the interpretation stage. At the level of descriptive verbal analysis I read the verbal text (narrative text and paratext) and coded all the references to the two key concepts of Africa and the African being.

In addition to analysing simple mentions of Africa and the African being, I applied the link that Janks (1997) makes between CDA and Halliday's (1985) systemic functional linguistics. I therefore focused on five aspects of functional grammar: lexicalisation; referential cohesion devices; the use of nominalisation; the use of active and passive voice; and patterns of transitivity.

When analysing for lexicalisation I not only looked at how often the concepts of Africa and the African being were used, but especially at the alternative words or synonyms that were used in their place (Janks, 1997; Luke, 1997; Nieuwenhuis, 2006). I therefore looked at nouns that were used in each textbook to refer to Africa and the African being (including names of specific countries of Africa and African people). For example, the analysed textbooks lexicalised Africa as "sub-Saharan Africa," or "Tropical Africa" (Textbook 1:53). This revealed how the concept of Africa was constructed in the textbooks as not representative of the whole geopolitical space that is known as Africa.

Analysing nominalisation in the text entailed my analysing the way verbs related to Africa and the African being were converted into nouns (Janks, 1997; Luke, nd, Nieuwenhuis, 2006). To exemplify, the textbooks had conflicting representations of African heads of state. In some cases they were nominalised as "African leaders" (Textbook 1:75; Textbook 2:60; Textbook 3:106; Textbook 4:79) while in other cases they were "rulers" (Textbook 3: 98) or "dictators" (Textbook 1:77, Textbook 2:60, 63, Textbook 4:85). This was very useful in that it revealed not only the stereotype of Africa and Africans, but other characteristics such as the agency with which these concepts were associated.

The analysis of the use of the active and passive voice also aimed at arriving at an understanding of the agency that the textbooks were vesting within the hands of Africa and the African beings. Similar sentences whose only difference is the active and passive voice connote different meanings (Janks, 
1997; Luke, 1997). For example, Textbook 4 (77) explains "the internal and external factors affecting Africa at this crucial time." In such a statement, Africa is not in the active voice, and that represents it as lacking in agency. Instead, Africa is here represented as a passive subject upon whom deeds are acted.

I also analysed for referential cohesive devices which presented another form of reference to Africa and the African being(s) such as referential cohesive devices (pronouns). For example, in the statement, "We can see that the reasons for Africa's relative backwardness," (Textbook 1:79), the use of the pronoun "we" separates South Africa from the rest of Africa. Similarly, the absence of gender-specific pronouns to refer to Africa shows attempts in the textbooks to present Africa as gender-neutral.

Finally, analysing transitivity was a more extensive task than the other four. However, this method was most relevant in that it analysed more deeply the historical processes associated with Africa and the African being(s). These processes can be identified through an analysis of the activities that are linked to the constructs. Transitivity analysis entailed identifying all the verbs associated with the constructs under focus and explaining the processes they represent (Janks, 1997; Barnard, 2003). An example is the statement in Textbook 2 (49) that "some African states opted to pursue new forms of colonialism or neo-colonialism after independence.” The verb "opted” implies that the decisions of the post-colonial African governments were a mental process which was thus informed by their political values. Linguists identify at least six forms of transitivity and these are material processes; verbal processes; mental processes; relational processes; behavioural processes and existential processes (Janks, 1997; Barnard, 2003). Although some researchers do not analyse for all processes, the nature of my study informs my decision to use them all. This is because of all the items I analysed, transitivity reveals more of the textbook producers' constructions, sometimes done subconsciously (Janks, 1997).

\section{Description: Visual text}

CDA provided an apt methodology to analyse visuals as text since I viewed visual text to be corroborating rather than competing with verbal text in the construction of African consciousness. Although there is no specific CDAbased method of visual analysis, according to Janks (1997) the way to go about 
this is to apply visual semiotics. This method entails an acknowledgement that visuals are signs which comprise signifiers that represent a particular meaning (the signified). It should be clarified that visual semiotics at a functional level does not aptly correspond with CDA since it is founded in structuralism and CDA is basically a poststructuralist methodology. However, Janks (1997) maintains that aspects of visual semiotics do tally with CDA. For my study, from the three types of visual semiotics, I found symbolic visual semiotics to be most useful. ${ }^{1}$ Firstly, a symbol assumes arbitrary nature, whereby meaning is constructed through agreement or habit. Secondly, words (verbal text) are also symbolic since their meaning is just as arbitrary.

In applying visual semiotics to my CDA framework I also started from Fairclough's dimension of description. At this point I provided descriptions of the visuals that were associated with Africa and the African being(s). For each visual, I analysed the components and what meaning they could represent in relation to my focus. The map of Africa in Image 1 which excludes the islands such as Mauritius or Seychelles speaks to the textbook's spatial notion of Africa. This can also be called denotation or analysis at the first level of articulation (Noble \& Bestley, 2005; Chandler, 2007). Besides analysing what was in the visuals, I also looked at their prominence or lack of it. I achieved this by considering issues such as the size of the image and its position in the chapter or on the page (Janks, 1997). For example, the drawing featuring Africa as a mother's womb is placed at the beginning of the selected chapter in Textbook 1 and covers the whole page thus making a bigger impression on the textbook user than the others. Some images had captions and these captions are meant to make the reader gain a stronger impression of the meanings being conveyed. For example, the captions helped me identify the time frame, the space and the people involved in the visual. I also needed to find the link (if any) between the lexicalisation in the captions and the visuals. I therefore analysed the lexicalisation of the visuals using the method applied for verbal analysis.

1 One of the pioneers of visual semiotics, Charles Pierce identified three types: iconic, symbolic and indexical. 


\section{Examples of visuals from the analysed textbooks}

Image 2: Map of Africa in 1991, showing date of independence
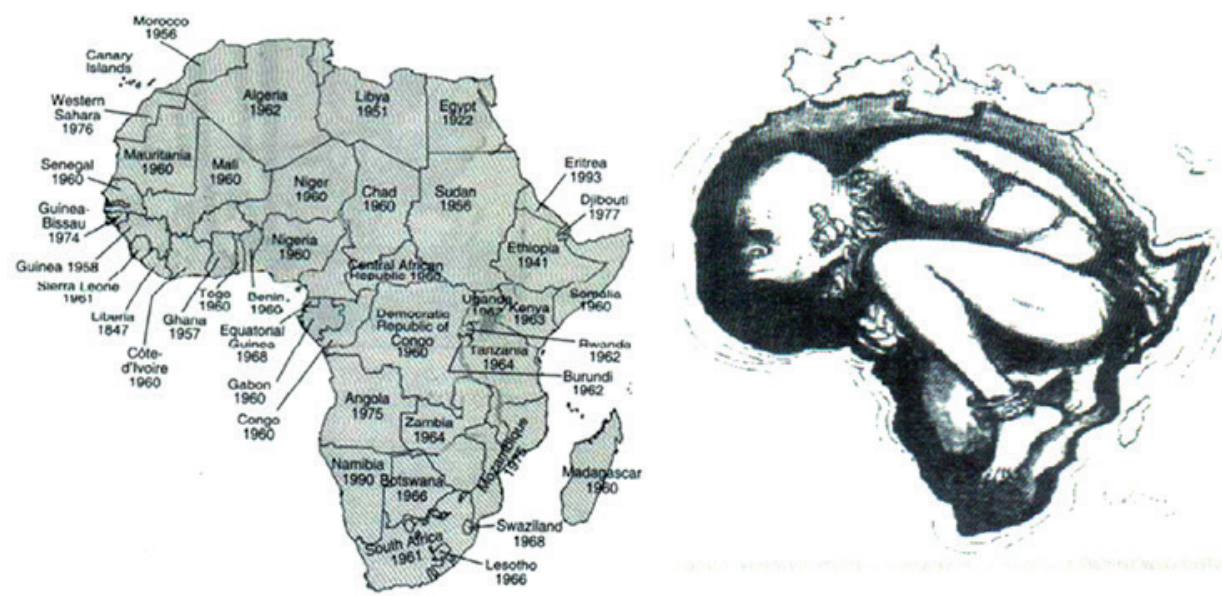

Source: Friedman et al., 2007:58; Bartels et al., 2006:53.

Image 3: This bar graph shows real and projected population growth for various regions of the world

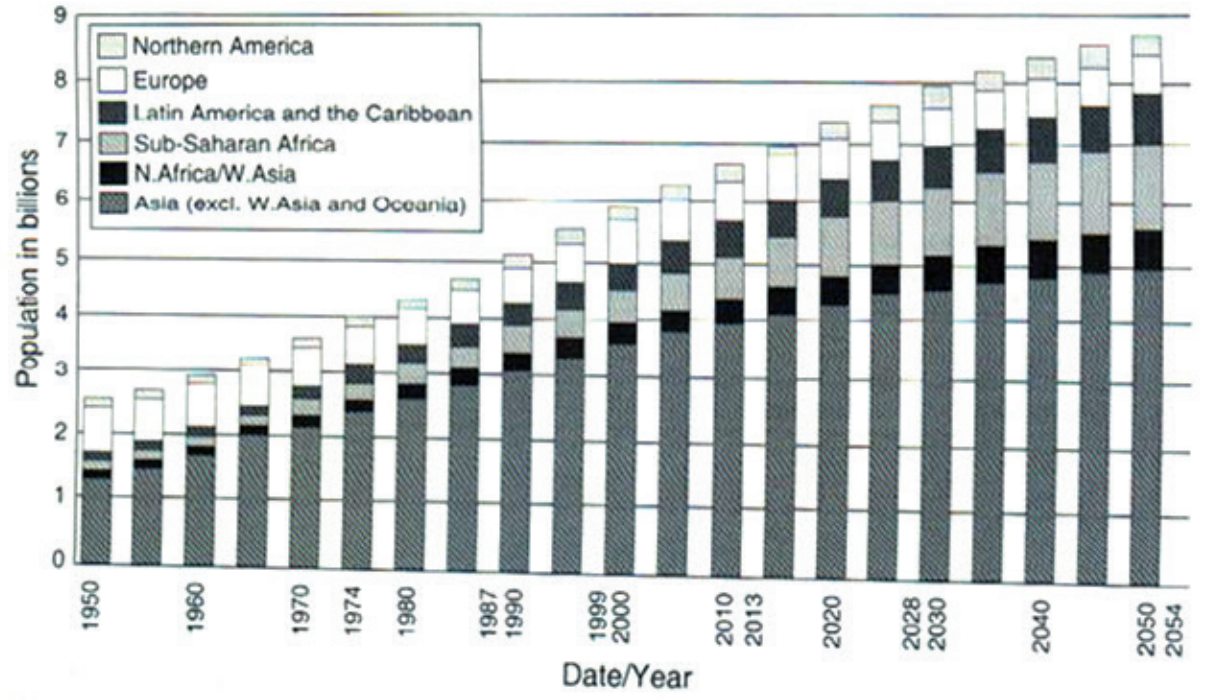

Source: Bartels et al., 2006:91. 
Image 4: This British cartoon shows Africa welcoming the rivalry between the super powers over Africa

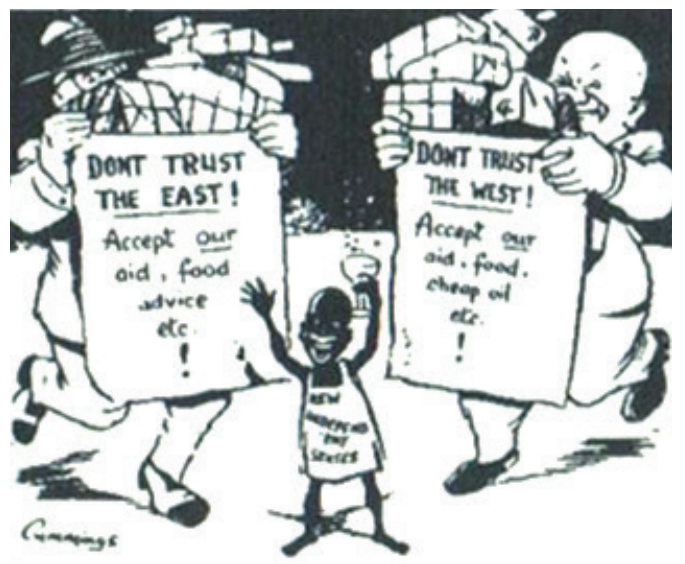

Source: Bottaro et al., 2006:109.

\section{Interpretation: Verbal and visual text}

The descriptive data from both verbal and visual analysis was useful only as far as obtaining a picture of the representation of Africa and the African being(s) was concerned. To further enrich my findings, I moved into the dimension represented by Fairclough's box of the analysis of the discourse practice as indicated in Image 1. This entailed interpreting the descriptions according to "the context of production and reception" (Janks, 1997:333). To analyse the descriptive data through the lens of the context, I considered two types of context: situational context and intertextual context.

In doing the situational context analysis I scrutinised the data through space and time (Janks, 1997). In other words, I made use of my understanding of the discourses on Africa and Africanness in the South African context within the time that the textbooks were published. This is because textbooks published within a particular time-period are bound to be influenced by the discourses and practices of the time. For example, the use of lexicalisations such as Tropical Africa in the description of Africa reveals an exceptionalism of South Africa, North Africa and the islands of Africa. The situational context supports such discourses of South African exceptionalism, perceiving South Africa to be exceptional to the general view of Africa. 
To strengthen my interpretation, I also analysed the intertextual context within this dimension of CDA. I approached this analysis in two ways: firstly by collating the findings from the visual and verbal text, and secondly by collating the findings from the different textbooks. For example, the graph in Image 3 supports the notion of Sub-Saharan Africa that is also pronounced in the verbal text. In CDA, intertextual analysis is meant to strengthen findings from a single text and it is for this reason that it is always recommended to analyse more than one text (Janks, 1997). Not only did I analyse the component parts of the visuals, but also their interrelatedness to each other and to the whole (LaSpina, 1998). For example, Image 2 shows a map, a drawing, a cartoon and a graph, but they individually and collectively represent the meaning of Africa according to the textbooks. This means that by the end of the interpretive analysis of visual text, I had found "the key to its coherence" (LaSpina, 1998:96). In simple terms, the process of interpretation revealed the meanings of Africa and Africanness in the textbooks.

\section{Explanation: Verbal and visual text}

The final dimension of my textbook analysis was explanation in which I made sense of the interpretation of the findings in relation to discourses emanating out of the context. This kind of analysis is done as illustrated in Fairclough's Box 1 in Image 1 (Janks, 1997). In practising social analysis I was looking at the dominant discourses as disseminated through educational discourse and use them to explain the findings. For example, the South African educational discourses are characterised by issues such as inclusion, human rights and democracy. However, the findings showed cases of both inclusion and exclusion when it came to South Africa's African identity.

At the level of description and interpretation, I relied mostly on the conceptual framework of African consciousness to make sense of the data. It is at the level of explanation that the theoretical framework of discursive postcolonialism became of invaluable relevance. I therefore used the theory (discursive postcolonialism) to explain the concept (African consciousness). For instance, postcolonialism speaks to the hybridity of Africa and the African being as a result of the colonial experience. It also explains the nature of the postcolonial textbook in postcolonial Africa. Therefore, applying CDA as a methodology meant that I not only described my findings but I was able to theorise them. 


\section{Methodological reflections}

My initial understanding of the nature of text had a huge bearing on the methodological choices that I made at the outset. For example, I had bought into the argument by LaSpina (1998) and Väisänen (2008) that all data that is found in textbooks is text since it has a certain meaning that it conveys. This view, I had shown, had support from CDA scholars such as Janks (1997) who argued that text comprises signs which can be either verbal or visual. However, even though I worked under this premise, some complications were revealed as the analysis unfolded.

Most of the literature referred to on the nature of text focused mainly on language (and thus verbal text) and not visuals (Donlan, 1980; Frier, 1998; Paxton, 1999; Jeans, 2005; Foster \& Crawford, 2006). The descriptions and interpretations of findings demonstrated that the data from the verbal and the visual text spoke to basically the same themes although in comparison, the visual text produced less data. For example, the visual data on the spatial notion of the African being was minimal compared to the verbal data. Therefore, visuals in the analysed textbooks can be argued to have been more complementary to the verbal text than saying their own stand-alone representations (Frier, 1998; Osler, 1994). This study therefore revealed that although visuals can be considered text, it is more worthwhile to study them together with verbal text since some visuals do not have detailed captions and on their own might be easily misinterpreted. A case in point is the collage in Textbook 1 (77) showing negative experiences such as war, famine, abuse and dictatorship. On their own they quickly construct Africa negatively and it takes the explanations in the verbal text to understand that the textbook is attributing such negativity to the Western world. In addition, the application of CDA to visual text was even more subjective than it was to the verbal text. For example, I interpreted a picture of children at school not wearing school uniforms as a sign of material poverty (Textbook 4:94). However, in reality and depending on the context, some children do not wear school uniforms simply because their schools do not have school uniform policies or they are opposed to rigid educational systems. Therefore it is subjective to view lack of school uniforms as signalling material poverty and this interpretation is informed by my contextual understanding. Faced with such subjectivity, I had to rely on the findings from the verbal text to contextualise the meaning of such visual text. Therefore, I arrived at the conclusion that while verbal text can construct deeper meanings on its own, some visual text will require 
complementary verbal text to construct comprehensive representations.

Another of the methodological complications in the analysis was the realisation that not all the visuals in the textbooks were actually produced by the textbook publishers. This was especially so for pictures of which some are in the public domain thus diminishing what, according to Paxton (1999:318), can be termed as "authorial voice." Although it can be acknowledged that the textbook publishers did not necessarily create all the visuals in the textbooks, I maintain their selection is not innocent either. In addition, if the visuals were already in the public domain, it then implies that the textbooks are confirming the discourses in the public already and not really constructing new ones (Osler, 1994). This then supports the argument that discourses at a macro-level and micro-level can influence discourses at the meso-level of history textbooks.

From my analysis of the textbooks I also noted, that sometimes silences can be telling. This was not new knowledge as literature shows that inclusion and occlusion both work to evince particular constructions in the textbooks (Millas, 1991; Wertsch, 2000). It was significant in this study that although Fairclough's CDA focuses on linguistic choices and visual representation, silences are equally important. For example, without noticing the omission of islands from the meaning of Africa or the silences on South Africa, it would have been difficult to understand the exceptionalism that is promoted in the textbooks. Therefore although Fairclough's CDA was largely useful, there were certain aspects that could not be fully encompassed.

There were also other aspects of CDA that I did not fully utilise since they did not completely relate to the phenomena on which I was focusing. For example, although I did transitivity analysis as suggested I did not apply it fully on the basis of Janks' (1997) advice that a full application is for very large scale studies. It should also be noted that I had found very limited evidence of the application of CDA in textbook analysis. I therefore had to adapt the methodology to my study. For example, while Fairclough's CDA suggests that the three levels of analysis (description, interpretation and explanation) be done and presented simultaneously, I separated them. In doing so, I had to engage with the deeper meanings of description, interpretation and explanation. Doing all of them together would have been easier had I been analysing very limited text, but for a large scale study, presentation of such data would have been cumbersome. It was my view that separating the three methodological moves would make the findings more comprehensible and 
also conform to the general structural conventions of writing research reports.

Finally, while conducting CDA, the temptation was to become attracted to other forms of CDA. Indeed, many new forms of CDA have emerged since the rise of functional linguistics (Gee, 2004; Rogers, 2004; Breeze, 2011; Tenorio, 2011). Therefore, the type of CDA that I used was basic. In fact, Fairclough (2013) himself has also further published new developments of his CDA; however his CDA is still rooted in the basic functional linguistics although he places more emphasis on hegemony and relational discourses in a capitalistic world. I decided to adhere to one form of CDA in order to keep my focus. I therefore chose the CDA positioning that served the purpose of my study in terms of understanding representation in text.

\section{Conclusion}

While there are many aspects to explore in history textbook research, this article's focus is on the application of CDA as an alternative methodology for the analysis of history textbooks. While the details of the larger-scale study can be accessed in other papers, in this paper I only reflected on my methodological choices. The reflection shows that applying CDA in history textbook analysis studies is fraught with challenges that mainly stem from its roots outside history education. The existence of multiple CDA positionings also reflects how scholars have tried to adapt it to fit different fields and studies. I take this, not as a weakness, but an availability of methodological options for different studies. My rationale for applying CDA was strong enough to make me adapt its basic tenets to my study. On reflection, I conclude that CDA can still be applied to worthwhile effect in the analysis of history textbooks if it is adapted fittingly and justifiably to the particular study.

\section{References}

Barnard, C 2003. Language, ideology, and Japanese history textbooks. London: Routledge Curzon.

Bottaro, J, Visser, P \& Worden, N 2006. Oxford in search of history Grade 12. Oxford: Oxford University Press.

Breeze, R 2011. Critical discourse analysis and its critics. Pragmatics, 21(4):493-525. 
Chandler, D 2007. Semiotics: The basics. London: Routledge.

Claire, H, Deftereos, R, Dugmore, C, Ramoroka, D, Van Reenen, V \& Titus, V 2007. Making History Grade 12. Johannesburg: Heinemann.

Cohen, L, Manion, L \& Morrison, K 2009. Research methods in education, 8. London: Routledge.

Crawford, K 2000. Researching the ideological and political role of the history textbook - Issues and methods. International Journal of History Learning, Teaching and Research, 1(1).

Dlamini, N, du Rand, S, Haw, S, Karumbidza, JB, Macallister, P, Middlebrook, T, Oliver, P \& Rogers, A 2007. Shuters History Grade 12. Pietermaritzburg: Shuter \& Shooter.

Donlan, A 1980. Locating main ideas in history textbooks. Journal of Reading, 24(2):135-140.

Fairclough, N 1995. Critical discourse analysis. London: Longman.

Firer, R 1998. Human rights in history and civics textbooks: The case of Israel. Curriculum Inquiry, 28(2):195-208.

Foster, S \& Crawford, K 2006. What shall we tell the children: International perspectives on school history textbooks. Greenwich: Information Age Publishers.

Friedman, M, Kros, C, Mlambo, A, Saundders, C, Seleti, Y \& Jacobs, M 2007. Focus on history: Looking into the past Grade 12. Cape Town: Maskew Miller Longman.

Gee, JP 2004. Discourse analysis: What makes it critical? In: R Rogers (ed.). An introduction to critical discourse analysis in education. Mahwah: Lawrence Erlbaum Associates:19-50.

Halliday, MAK 1985. An introduction to functional grammar. London: Edward Arnold.

Henning, E, Van Rensburg, W \& Smit, B 2004. Finding your way in qualitative research. Pretoria: Van Schaik Publishers.

Huckin, T 2002. Critical discourse analysis and the discourse of condescension. In: E Barton \& G Stygall (ed.). Discourse studies in composition. Cresskill: Hampton:155-176.

Janks, H 1997. Critical discourse analysis as a research tool. Discourse: Studies in the Cultural Politics of Education, 18(3):239-242.

Jeans, RB 2005. Victims or victimizers? museums, textbooks, and the war debate in contemporary Japan. The Journal of Military History, 69(1):149-195. 
Johnsen, EB 2001. Textbooks in the Kaleidoscope. Tønsberg: Høgskolen i Vestfold.

LaSpina, JA 1998. The visual turn and the transformation of the textbook. Mahwah: Lawrence Erlbaum Associates.

Lavere, DB 2008. The quality of pedagogical exercises in U.S. history textbooks. The Social Studies, 99(1):3-7.

Lebrun, J, Lenoir, Y, Laforest, M, Larose, F, Roy, G, Spallanzani, C \& Pearson, M 2002. Past and current trends in the analysis of textbooks in a Quebec context. Curriculum Inquiry, 32(1):51-83.

Luke, A 1997. Introduction: Theory and practice in critical discourse analysis. In L Saha (ed). International Encyclopaedia of the Sociology of Education, Elsevier Science Ltd.

Maposa, MT 2014. An analysis of the construction of African consciousness in South African history textbooks. Unpublished Ph.D thesis. Durban: University of KwaZuluNatal.

Millas, H 1991. History textbooks in Greece and Turkey. History Workshop, 31:21-33.

Morgan, K 2010. Reflexive grappling with theory and methods of text analysis: Race and racism represented in history textbooks. South African Historical Journal, 62(4):753-770.

Morgan, K \& Henning, E 2013. Designing a tool for history textbook analysis. Forum Qualitative Social Research, 14(1):1-21.

Mouton, J 2011. How to succeed in your master's and doctoral studies: A South African guide and resource book. Pretoria: Van Schaik.

Naseem, MA 2008. Texts of war/texts of peace: Dismantling violence and constructing peace in textbooks and educational media. Paper presented at the Ninth International Conference on Textbooks and Educational Media: Peace, Democratization and Reconciliation in Textbooks and Educational Media, September 2007, Tonsberg Norway.

Nicholls, J 2003. Methods in school textbook research. International Journal of Historical Learning, Teaching and Research, 3(2). No page numbers.

Nieuwenhuis, J 2007. Qualitative research designs and data gathering techniques. In: K Maree (ed.). First steps in research. Pretoria: Van Schaik.

Noble, I \& Bestley, R 2005. Visual research: An introduction to research methodologies in graphic design. London: AVA Books (UK) Ltd. 
Osler, A 1994. Still hidden from history? The representation of women in recently published history textbooks. Oxford Review of Education, 20(2):219-235.

Oteíza, T \& Pinto, D 2008. Agency, responsibility and silence in the construction of contemporary history in Chile and Spain. Discourse Society, 19(3):333-358.

Paxton, RJ 1999 A deafening silence: History textbooks and the students who read them. Review of Educational Research, 69(3):315-339.

Peräkylä, A 2005. Analysing talk and text. In: NK Denzin \& YS Lincoln (eds.). Collecting and interpreting qualitative materials. Los Angeles: SAGE Publications.

Pingel, F 2010. UNESCO Guidebook on textbook research and textbook revision. Paris: United Nations Educational, Scientific and Cultural Organization/ Braunschweig: Georg Eckert Institute for International Textbook Research.

Rogers, R 2004. An introduction to critical discourse analysis in education. Mahwah: Lawrence Erlbaum Associates.

Selander, S 2008. Designs of democracy in contemporary learning resources. Paper presented at the Ninth International Conference on Textbooks and Educational Media: Peace, Democratization and Reconciliation in Textbooks and Educational Media, September 2007, Tonsberg Norway.

Swanson, RA 2014. A relationship analysis: A professor, 500 students, and an assigned textbook. The History Teacher, 47(2):289-302.

Tenorio, EH 2011. Critical discourse analysis, an overview. Nordic Journal of English Studies, 10(1):183-210.

Väisänen, J 2008. Visual texts in Finnish history textbooks. Paper presented at the Textbooks and Educational Media in the Learning Environment workshop.

Weinbrenner, P 1992. Methodologies of textbook analysis used to date. In: H Bourdillon (ed.). History and Social studies: Methodologies of textbook analysis. Amsterdam: Swets \& Zeitlinger.

Wertsch, JV 2000. Specific narratives and schematic narrative templates. In: P Seixas (ed.). Theorizing historical consciousness. Toronto: University of Toronto Press. 